\title{
Polish Hydrogen Strategy - regulatory challenges in the European perspective
}

ABstract: On 14 January 2021, the Polish Ministry of Climate and the Environment submitted for public consultation the draft Polish Hydrogen Strategy until 2030 with a perspective until 2040. The project defines goals and activities related to developing national competencies and technologies for building a low-emission hydrogen economy. The draft announces the preparation of the "Hydrogen Law", which is to be a package of changes to currently existing acts, particularly the Polish Energy Law. However, the proposals presented in the strategy do not seem to be fully consistent with the vision of the development of the future regulation of the hydrogen market presented by the European Commission. The article presents the Polish Hydrogen Strategy's most important assumptions regarding the proposed legislative changes and discusses them in the context of the European strategy. The main focus is on two aspects related to the planned legislative changes that seem to be the most important at this stage in order to stimulate the development of the hydrogen market: the definition of hydrogen and the decision upon which production methods will be supported, and the future regulation of the hydrogen market.

KeYwords: Polish Hydrogen Strategy, hydrogen, decarbonized gases, green hydrogen, Polish Hydrogen Law

Corresponding Author: Dagmara Dragan; e-mail: dagmaradragan@gmail.com

${ }^{1}$ Faculty of Law and Administration, Adam Mickiewicz University in Poznań, Poland; ORCID iD: 0000-0002-8737-0009; e-mail: dagmaradragan@gmail.com

2021. The Author(s). This is an open-access article distributed under the terms of the Creative Commons Attribution-ShareAlike International License (CC BY-SA 4.0, http://creativecommons.org/licenses/by-sa/4.0/), which permits use, distribution, and reproduction in any medium, provided that the Article is properly cited. 


\section{Introduction}

On 14 January 2021, the Polish Ministry of Climate and the Environment submitted for public consultation the draft Polish Hydrogen Strategy until 2030 with a perspective until 2040 (MCE 2021). The project defines goals and activities related to developing national competencies and technologies to build a low-emission hydrogen economy. As part of the project, it is planned to publish a draft of the Polish "Hydrogen Law" in 2021, which would be a package of regulations amending existing acts such as the Energy Law or the Act on Electromobility. Although the list of changes proposed in the strategy is not long and the "Hydrogen Law" draft should undoubtedly be more comprehensive than has been described, it is possible to read the regulatory direction the Polish government intends to take. However, this direction does not seem to be entirely consistent with the European Commission's proposals presented in "A Hydrogen Strategy for a Climate-Neutral Europe" (EC 2020). The inconsistencies in the approach are particularly visible in two aspects which are the most important at this stage: defining hydrogen and adopting criteria for granting state aid to specific types of hydrogen and adopting a regulatory model for the market.

This article presents the Polish Hydrogen Strategy's most important assumptions regarding the proposed legislative changes and discusses them in the context of the European strategy. The main focus was on two aspects related to the planned legislative changes that seem to be the most important at this stage in order to stimulate the development of the hydrogen market: the definition of hydrogen and the decision on which production methods will be supported, and the future regulation of the hydrogen market. The purpose of this article is to show inconsistencies between Poland and the EU Hydrogen Strategy, including inconsistencies with regard to the planned legislation on the development of the hydrogen sector, which may prevent the implementation of the Polish government's plans.

\section{EU hydrogen-market development strategy}

Hydrogen is considered to be the fuel of the future, the use of which is to be one of the pillars of the transition to a carbon-neutral economy. Countries worldwide already have plans for producing so-called green hydrogen, which is to be produced using renewable energy sources during the electrolysis process and its subsequent use for energy storage or as part of a sector-coupling strategy. The European Union also has such plans, for which clean hydrogen technologies are one of the main elements of the energy transformation announced under the European Green Deal (EC 2019).

At present, more than half of the total hydrogen consumption in Europe occurs in just four countries: Germany (22\%), the Netherlands (14\%), Poland (9\%) and Belgium (7\%) (HE 2020). 
The total hydrogen production capacity in Europe at the end of 2018 was around 11.5 million tons (Mt) per year, and the most common method of hydrogen supply is on-site captive hydrogen production with almost two-thirds of all hydrogen production capacity. Today, the vast majority of hydrogen is produced from fossil fuels, which is the least costly solution for hydrogen production, but it is not sustainable. The steam reforming of natural gas is the most common and established technology for the large-scale production of this industrial gas, which is widely used for oil refining, ammonia synthesis or any other bulk hydrogen production; however, its emission factor amounts to 285 grams of $\mathrm{CO}_{2}$ per kilowatt-hour $(\mathrm{kWh})\left(9.5\right.$ kilograms of $\mathrm{CO}_{2}$ per kilogram of hydrogen). Another widely-used production method is coal gasification, where the emission factor is even greater - 675 grams of $\mathrm{CO}_{2}$ per kilowatt of hydrogen (IRENA 2019). Solutions to the problem of high emissivity of hydrogen production technologies include electrolysis and carbon capture and storage (CCS). Notwithstanding, these are still emerging technologies - currently, electrolyzers are available on small scale $(<1 \mathrm{MW})$ production; demonstration projects for larger scales (up to $10 \mathrm{MW}$ ) are currently underway (FCH 2019). The total installed capacity of electrolyzers in Europe is around $1 \mathrm{GW}$, which amounts to around $1.6 \%$ of the total hydrogen production capacity (Kanellopoulos and Blanco Reano 2019).

In order to plan and support the development of sustainable hydrogen technologies in Europe, the European Commission has developed "A Hydrogen Strategy for a Climate-Neutral Europe", in which the EC divided the development phases of this branch of the economy into three stages: in the first phase, from 2020 to 2024, the strategic objective is to install at least $6 \mathrm{GW}$ of renewable hydrogen electrolysers in the EU and the production of up to 1 million tons of renewable hydrogen; in the second phase, from 2025 to 2030, a strategic objective is to install at least $40 \mathrm{GW}$ of renewable hydrogen electrolyzers by 2030 and the production of up to 10 million tons of renewable hydrogen in the EU - in this phase, hydrogen will be a part of an integrated energy system and the sustainable production methods will gradually become cost-competitive; in the third and final phase, from 2030 onwards and towards 2050, renewable hydrogen technologies should reach maturity and be deployed on a large scale to reach all sectors.

The strategy outlines the most important possible future uses for hydrogen in end-use sectors, particularly in transport, industry, and electricity generation. The fundamental issue of infrastructure was also discussed, including proposals to use the existing gas assets. As part of its political and legislative plans, the Commission intends, inter alia, to develop a common threshold or a common standard for low carbon-hydrogen and comprehensive terminology and pan-European certification criteria for renewable and low-carbon hydrogen. The strategy also proposes possible support systems for the development of renewable hydrogen, including the use of Carbon Contracts for Difference.

The Polish Hydrogen Strategy is largely in line with the hydrogen strategy for a climate-neutral Europe in terms of targets and anticipated future hydrogen uses. However, some differences are visible, primarily related to the specificity of the Polish hydrogen economy, the high demand for this industrial gas in Poland for the purposes of refining or ammonia production, and the possibility of using so-called grey hydrogen produced using fossil fuels. These differences, particularly in the approach to the proposed legislative changes, are discussed later in this article. 


\section{Production and use of hydrogen in Poland - the current state}

Poland is currently ranked fifth in the global ranking of hydrogen producers (MCE 2021) and third in the European Union (HE 2020); however, the share of hydrogen production in the water-electrolysis process is negligible. In 2015, the total production of hydrogen in Poland was estimated at 1 million tons, which accounted for over 10\% of hydrogen consumption in Europe. According to the Polish Central Statistical Office, in 2019, over 20 million $\mathrm{m}^{3}$ of hydrogen was sold in Poland, with a total value of over PLN 22 million (CSO 2019b).

The largest producer of hydrogen in Poland is currently Grupa Azoty SA, a company operating in the sector of mineral fertilizers, engineering plastics, as well as OXO products and other chemicals, which produces about 420 thousand tons of hydrogen annually and its share in the hydrogen production market reaches $42 \%$ (MCE 2021). Oil companies are also significant producers of hydrogen: Polski Koncern Naftowy Orlen SA, also involved in the production of nitrogen fertilizers through its daughter company - Anwil SA, and Grupa Lotos SA produce about 145 thousand tons of hydrogen each year, and therefore each one separately has approximately $14 \%$ of the market share; however, it should be noted that, according to other sources, the production of Grupa Lotos SA in 2015, was much lower - at that time it amounted to about 59 thousand tons (PIE 2019). Coking plants (Koksownia Przyjaźń owned by JSW KOKS SA, a company from the Jastrzębska Spółka Węglowa SA. Capital Group and Koksownia Zdzieszowice owned by Arcelor Mittal Poland SA (PIE 2019)) also have a significant share in the production of hydrogen. Other entities own the remaining $23 \%$ of the hydrogen market. The development of green hydrogen is planned in the coming years especially in Eastern Wielkopolska, where the company Zespół Elektrowni Pątnów Adamów Konin SA, which is the owner of a lignite-based mine and power plant, has installed a $2.5 \mathrm{MW}$ electrolyzer and has another planned, producing hydrogen based on electrical energy produced in a biogas plant (ZEPAK 2020).

In Poland, hydrogen is primarily used in the chemical industry for, among others purposes, the production of ammonia from which fertilizers are obtained and in the petrochemical industry. Most of the hydrogen in Poland is consumed by companies that produce it, and only a small volume is traded on the market - this volume usually comes from excess capacity in hydrogen production units in chemical plants and refineries, or is a by-product, or is imported from abroad - mainly from Germany and the Czech Republic (HE 2020). Obviously, hydrogen also has many other applications, which is particularly important in the context of the development of its production - it can be used not only in the production of steel and glass, in medicine and in the food industry but also for reducing (e.g. metal oxides) and hydrogenating (hardening) fats. It is used to obtain high temperatures in oxygen-hydrogen burners. Hydrogen is of great importance as a propelling material (mixed with oxygen) in space rockets. 


\section{Goals of the Polish Hydrogen Strategy}

On 14 January 2021, the Polish Ministry of Climate and the Environment submitted for public consultation the draft Polish Hydrogen Strategy until 2030 with a perspective until 2040. The project defines goals and activities related to developing national competencies and technologies to build a low-emission hydrogen economy. They relate to the three sectors of hydrogen use - energy, transport, and industry - as well as to its production, distribution and the necessary legal changes and financing. The public consultation will run until 14 February 2021.

The strategy describes the possibilities and sets tasks in six areas: implementing hydrogen technologies in the energy sector, the use of hydrogen in transport, the use of green hydrogen in industry, the launch of new installations for hydrogen production and its distribution with new and existing infrastructure. In each of these areas, goals have been set to be achieved by 2025 and 2030, including increasing production capacity, installing electrolyzers, purchasing hydrogen-powered buses, etc. The use of hydrogen is expected to contribute to stabilizing the energy system, particularly concerning the planned increase in renewable energy sources and sector coupling.

The Polish Hydrogen Strategy stands out from other strategies, including "A Hydrogen Strategy for a Climate-Neutral Europe", firstly, because it assumes some alternative elements of the hydrogen economy development, particularly the use of so-called grey hydrogen and hydrogen produced from nuclear energy, including small-scale nuclear energy (the use of high-temperature nuclear reactors - HTR), and secondly, because, compared to many other countries in Western Europe, Poland will start from another place in the development of the hydrogen economy - it has significant production of hydrogen from fossil fuels, the use of which is necessary for the refining industry, and at the same time a relatively small share of renewable energy sources in total energy production (CSO 2019a). Implementing the Polish Hydrogen Strategy plans requires several legislative changes, some of which have already been proposed in the strategy. However, in the opinion of the author of this article, these are definitely not all the necessary changes, and some of the proposals should be assessed critically. This article primarily focuses on two aspects related to the planned legislative changes that seem to be the most important at this stage in order to stimulate the development of the hydrogen market: the definition of hydrogen and the decision on which production methods will be supported, and the future regulation of the hydrogen market.

\section{Definitions of hydrogen and its production technologies}

The Polish Hydrogen Strategy presents the nomenclature and classification of the types of hydrogen, depending on the emissivity of the method of its production - the approach proposed in the strategy is to be "technologically neutral", which in a way contradicts the current proposals 
of the European Commission, expressed in "A Hydrogen Strategy for a Climate-Neutral Europe", which gives priority to so-called green hydrogen.

Two main categories of hydrogen have been proposed in the Polish Hydrogen Strategy:

४ The first category is conventional hydrogen, produced in various processes that use fossil fuels, mainly using natural gas steam reforming, coal gasification or coke oven gas separation, with an emissivity greater than $5.8 \mathrm{~kg} \mathrm{CO}_{2} \mathrm{eq} / \mathrm{kg} \mathrm{H}$. This level of emission is achieved with the use of natural gas in production; therefore, the authors of the Polish Hydrogen Strategy prefer to use this energy carrier for hydrogen production in a transitional period instead of coal, with the use of which the emissivity of hydrogen production increases to over $10 \mathrm{~kg}$ $\mathrm{CO}_{2} \mathrm{eq} / \mathrm{kg} \mathrm{H}_{2}$. The main advantage of this type of hydrogen is its price, as it is the cheapest production method.

$\downarrow$ The second category is low-carbon hydrogen produced from non-renewable or renewable energy sources with a low carbon footprint. This type of hydrogen's emissivity is estimated to be less than $5.8 \mathrm{~kg} \mathrm{CO}_{2} \mathrm{eq} / \mathrm{kg} \mathrm{H}_{2}$. Various technologies can be used to produce this type of hydrogen, including the steam reforming of hydrocarbons with $\mathrm{CO}_{2}$ capture and storage (CCS) or $\mathrm{CO}_{2}$ capture and use (CCU), coal gasification from CCS or $\mathrm{CCU}$, biomass gasification from $\mathrm{CCS}$ or $\mathrm{CCU}$, electrolysis with use of electricity from renewable energy sources, electrolysis using electricity from conventional sources with CCS or CCU, pyrolysis, chemical processes for which the by-product is hydrogen, including the separation of hydrogen from coke-oven gas. The costs of using these technologies are influenced by several factors, including the price of gas and the costs of using CCS technology, which is still relatively high.

$\checkmark$ Among the types of hydrogen that should be classified as low-emission hydrogen, the Polish Hydrogen Strategy authors also indicated waste hydrogen generated as a by-product of chemical processes, which is classified as low-emission because the emission results from other processes in which it is inevitable. It is an approach which, if adopted and implemented in legal regulations by granting this type of hydrogen a low-emission status and providing it with support on a par with other technologies mentioned above, would favour Polish industry due to a substantial volume of hydrogen produced in this way. However, the proposal for such a qualification should be assessed negatively - the use of hydrogen in the economy is aimed at its decarbonization; therefore, it is necessary to promote the least emitting technologies of its production, including promoting the reduction of the emissivity of its production in the industry.

One of the most important issues distinguishing the Polish Hydrogen Strategy from "A Hydrogen Strategy for a Climate-Neutral Europe" is the approach to the classification of hydrogen types - the Polish strategy emphasizes that the precise numerical determination of hydrogen emissivity should replace the arbitrary assigning of "color" to it depending on the production technology. The criterion should be the amount of $\mathrm{CO}_{2}$ emitted throughout the production chain of one kilogram of hydrogen. For comparison, in the strategy proposed by the European Commission, the presented classification of the types of hydrogen refers only to the technology of its production, distinguishing, among others, electrolytic hydrogen, hydrogen from fossil fuels 
and hydrogen from fossil fuels with carbon dioxide capture (EC 2020). Although the European strategy discusses the production costs of individual types of hydrogen, it does not provide information on their emissivity and does not take into account the level of development of individual technologies and the market itself. The European Commission's approach prioritizes the use of electrolytic hydrogen by setting in the strategy the targets regarding the minimum production capacity of installed electrolyzers (EC 2020) or by designing direct and transparent, market-based support schemes allocated through competitive tenders exclusively for renewable hydrogen is widely criticized (GN 2020). This approach is accused of, inter alia, a lack of realism and the high cost of such a transformation. As Alex Barnes points out, enabling different approaches to compete (e.g., electrolysis, reforming, pyrolysis, biomethane) will help drive down decarbonisation costs, thereby making success more likely (Barnes 2020).

The Polish government takes a firm position that hydrogen support should be technologically neutral, which is in line with large Polish hydrogen producers' interests. According to unofficial information (Jakóbik 2021), it was the efforts of the Polish government that led to expressing this position during the COREPER meeting in December 2020, and then introducing it to the conclusions of the Council of the European Union, which stated, among others, that there are different safe and sustainable low-carbon technologies for the production of hydrogen that contribute to the rapid decarbonization and thus admitting that, at least in the transitional period, other technologies for producing hydrogen than electrolysis should also matter (Council EU 2020). Recently, the bridging role of low-carbon hydrogen was also highlighted by ENVI (ENVI 2021).

The Polish Hydrogen Strategy mentions two significant legislative changes related to the support of various types of hydrogen. Firstly, it describes the plans to introduce hydrogen production regulations from renewable energy sources to the act on renewable energy sources (RES Act 2015). Legislative changes are to include the implementation of the RED II directive (RED II Directive 2018) with regard to establishing a guarantee of origin system for hydrogen (RED II Directive 2018). However, the scope of other possible legislative changes is unknown; in particular, it is unknown whether other support systems applicable to the production of energy from renewable sources, such as auctions, are also predicted for this type of hydrogen. Secondly, the Polish Hydrogen Strategy also envisages changes related to hydrogen produced from nuclear energy - it is planned to recognize investments related to the production of this type of hydrogen as investments accompanying the preparation and implementation of investments in nuclear power facilities. This means that they will be covered by several procedural simplifications related to, inter alia, obtaining the necessary administrative decisions. The assumption that the development of the hydrogen market will be based on nuclear energy is another element that distinguishes the Polish strategy from the European one - the European strategy does not mention such a production method at all; additionally, it should be taken into account that Poland has no nuclear power plant as yet, and the commissioning of the first such plant is not planned until 2033 (PEP40 2021). 


\section{Legal regime related to hydrogen and gas infrastructure}

Regardless of how the hydrogen is generated, it must be transported if it is not produced directly at the point of use. As the International Energy Agency claims, pipelines are likely to be the most cost-effective long-term choice for local hydrogen distribution if there is a sufficiently large, sustained, and localized demand (IEA 2019). The primary means of transporting hydrogen through pipelines are networks adapted for this purpose, but it is also possible to blend hydrogen with natural gas and transport it through the natural gas transmission or distribution network. Blending hydrogen into existing natural gas pipeline networks may be an excellent development opportunity in the initial stage of market development and may provide a boost to hydrogen supply technologies; however, hydrogen blending faces several challenges (IEA 2019) and therefore this technology is not always considered desirable.

The Polish Hydrogen Strategy divides the tasks related to hydrogen transportation into two-time perspectives. By 2025, an analysis of the most optimal form of energy transmission for the development of the hydrogen economy is to be developed, taking into account the following technologies: electricity transmission, hydrogen transmission, the transmission of SNG through the existing gas network or hydrogen transmission through dedicated pipelines. In the next period, until 2030, selected sections of the gas network are to be adapted to the transmission and distribution of hydrogen blended with gas; dedicated pipelines are to be built, and SNG produced in P2G technology is to be injected into the gas networks. Therefore, in the Polish Hydrogen Strategy, the use of all the most important technologies in the field of hydrogen transportation is planned, including blending hydrogen with natural gas and its transmission through existing gas networks. The strategy even referred to the Polish Energy Policy until 2040, in which it was declared that by 2030 , the Polish gas network would be capable of transporting a mixture containing about $10 \%$ of so-called decarbonised gases (hydrogen and biomethane) (PEP40 2021). The strategy also referred to the gas directive (Directive EC 2009), in which the preamble states that the gas network should be ready for injecting biogas and biomethane, which in the understanding of the authors of the strategy, also extends to hydrogen and syngas. One of the strategy's tasks is the construction of new, dedicated hydrogen networks - the strategy even mentions the "hydrogen highway", which will extend from the north to the south of the country.

According to the survey results conducted by the Agency for the Cooperation of Energy Regulators (ACER) among European transmission system operators (ACER 2020), hydrogen has never been injected into Poland's gas network. In the current regulatory state, it is impossible due to the provisions on natural gas quality (Regulation ME 2010). However, Gaz-System SA - the Polish Transmission System Operator (TSO), in this survey was in favour of mixing hydrogen with natural gas, and what is more, the company is also researching the possibility of using this technology. Gaz-System also stated that in some sections of the gas transmission network in Poland, it is possible to transmit gas with an approximately $2 \%$ hydrogen admixture; nonetheless, TSO has so far not included any hydrogen-related projects in its development plans (PIE 2019). 
Furthermore, there are serious doubts about whether the gas network's current technical state in Poland will allow for a larger-scale blending of natural gas with hydrogen (PIE 2019). As for the networks dedicated to hydrogen transmission, such networks already exist in Poland, and they are intended for industrial use, most often connecting installations located within the same plant or nearby. The operation of these pipelines is currently not covered by any dedicated legal regulations. However, there are considerable technical obstacles to the long-distance transport of hydrogen via such networks (IEA 2019).

In addition to the above-mentioned technical obstacles, the Polish Hydrogen Strategy's implementation will also require overcoming regulatory challenges primarily related to whether the decarbonized hydrogen market should be regulated and to what extent. First of all, in the strategies, studies and articles published so far, there is a clear disagreement as to whether the hydrogen market, especially in its emerging phase, should be covered by regulations relating to gas infrastructure resulting primarily from the Gas Directive (Directive EC 2009), in particular, whether the principles of unbundling, the principle of third party access or the obligation to calculate tariffs and submit them to the national regulatory authority for approval, should apply to hydrogen-related activities.

The Polish Hydrogen Strategy describes three main legislative changes in the hydrogen market regulation, which are to be implemented into the Polish Energy Law Act (EL 1997). Firstly, it is planned to introduce a definition of hydrogen into the act, as it is currently unclear whether hydrogen should be classified as a gaseous fuel under this act or not and consequently, whether the activity in the hydrogen market should be regulated in the same way as the activity in the natural gas market. Secondly, it was proposed that the activity on this market should not be subject to the obligation to obtain a license, and thirdly, as part of determining the rules for the functioning of the hydrogen market, it was recommended not to implement the ownership unbundling rules until this market was adequately developed. It can therefore be concluded that the Polish government aims to ensure that the hydrogen market, at least in the initial stage of development, is not a regulated market at all or that it is regulated only to a specific, rather than an excessively wide, extent. Of course, it should be expected that the planned "Hydrogen Law" will comprehensively answer the questions regarding the scope of this regulation; however, the content of the Polish Hydrogen Strategy reveals the direction in which the Polish government will be heading when preparing the draft of this law.

The Polish government's intentions to regulate the hydrogen market only to a small extent may turn out to be inconsistent with the plans of the European Commission. The vision of this market's functioning presented by the Commission in "A Hydrogen Strategy for a Climate-Neutral Europe" is not entirely clear. On the one hand, the EC indicated that, particularly if it is an infrastructure covering a small area - for example, a production plant, the hydrogen distribution infrastructure may be subject to regulations similar to those currently applicable to closed distribution systems or direct gas pipelines (Directive EC 2009), which means that exemptions will apply to them, such as an exemption from the obligation to obtain a license or submit tariffs for approval. For the rest, the commission states that "infrastructure operators should remain neutral" in order not to distort the level playing field in the hydrogen market. Moreover, the 
commission is proposing to bring the hydrogen market to third party access rules and develop clear rules for connecting electrolyzers to the grid and licensing and transparent administrative procedures. In line with "A Hydrogen Strategy for a Climate-Neutral Europe", the provision of clear rules at the early stage of market development may help to avoid loss-making investments and the costs of interventions (EC 2020). The commission also announced the revision of gas legislation in 2021 for the competitive decarbonized gas market needs (EC 2020). Although it is not clear from the information provided what kind of regulatory framework the Commission wants to design for the hydrogen market, it seems likely that it will be closer to regulating the natural gas market than the Polish government would like and presented it in the Polish Hydrogen Strategy.

As already indicated, there is a clear disagreement among experts and stakeholders about regulating the hydrogen market, which concerns not only the vision of this market presented by the Polish government and the European Commission. In line with the Commission's vision seems to be the proposal of A. Piebalgs and Ch. Jones, who stated that at the current early stage of hydrogen infrastructure development, "the best way to establish the basic future hydrogen market rules would be to follow the logic and principles established for the regulation of the natural gas market through the Gas Regulation and Gas Directive" (Piebalgs and Jones 2021). The authors drew attention to the duplication of regulations concerning inter alia, third party access, and origin guarantees as particularly important. In turn, A. Barnes points out that due to the fact that the hydrogen market does not yet exist, imposing already very specific obligations on it comparable to those which are implemented for the gas market would prevent the development of hydrogen markets by the Member States in the way that suits them best (Barnes 2020). The author claims that "encouraging industry to kick start demand for decarbonization of gas by giving more commercial freedom is acceptable from a regulatory standpoint" and that "once the market is mature, then it will be possible to reconsider the framework, so long as there is sufficient regulatory certainty for investors" (Barnes 2020). A very similar approach was presented by ACER, which published very detailed proposals for the future draft regulation of the hydrogen market (ACER 2021). According to its white paper, "It should be noted that the current situation for discussing possible regulation for the transport of hydrogen is very different from the situation when regulation for gas and electricity networks was introduced" - hydrogen infrastructure still needs to be developed, while gas infrastructure was in place when three energy packages were implemented. ACER advocates a gradual approach to the regulation of hydrogen networks - the need for regulatory intervention for hydrogen network infrastructure should depend on how the hydrogen sector will evolve. ACER recommends that the national regulatory authorities should monitor when any possible regulation of hydrogen networks should kick in, based on pre-defined EU-wide principles, and that there should be clarity on when the regulation should kick in and what would be the general principles that would apply to future hydrogen infrastructure. Like others, ACER also recommends temporarily exempting business-to-business hydrogen networks from future regulations. ACER's recommendations may have a particularly significant impact on the shape of the future regulation on hydrogen infrastructure, which is why it is not without significance that they are generally in line with the Polish government's proposals. 
One of Poland's key issues in the coming decades will be the possibility of financial support for the construction of new gas infrastructure and the transformation of the existing infrastructure that could be used for the transport of decarbonized gases. Poland is at the stage of completing very important and capital-intensive projects, such as the expansion of the LNG Terminal in Świnoujście, the construction of the Baltic Pipe (a gas pipeline connecting Norway and Denmark with Poland) and the Poland-Lithuania gas interconnector (the so-called GIPL), and at the same time, plans to engage in new projects, such as the construction of the Floating Storage and Regasification Unit in the Bay of Gdańsk (PEP40 2021). Changing the approach to natural gas use in the European Union and recognizing this fuel as a fossil fuel on a par with coal would constitute a severe difficulty in the further development of these projects. The Polish government considers gaseous fuel as a transitional fuel in the period of the country's energy transformation, and the diversification of supplies of this raw material has been one of the most important aspects of the country's energy security for decades. The above-mentioned investments, such as the LNG Terminal, Baltic Pipe and GIPL, were completed largely due to their qualification on the list of Projects of Common Interest (PCI), which made it possible to obtain financial support for their implementation. However, the recently published new draft of the TEN-E Regulation (Proposal TEN-E 2020) clearly excludes gas infrastructure from being eligible for the PCI list and the possibility of obtaining financial support, which on the one hand may be a hindrance to the implementation of plans for the construction of new gas infrastructure (such as FSRU in the Gdansk Bay), but on the other hand, can be an excellent factor stimulating development infrastructure for decarbonized gases. The new draft TEN-E regulation provides in art. 4 point 3 that hydrogen projects will constitute a separate category of projects for which support is to be granted, but it is mainly projects based on renewable hydrogen that are to be supported. If the support is provided to promote hydrogen production from renewable energy sources, it may make it difficult for Poland to obtain financial support for building new infrastructure and transforming the existing infrastructure.

\section{Conclusions and recommendations}

Although, the Polish Hydrogen Strategy's assumptions are not very detailed, it is possible to deduce the directions in which the planned legislative changes will follow. They show a clear tendency to use the potential of Polish companies that already produce hydrogen on a very large scale, although it is hydrogen produced from fossil fuels. Indeed, it should be considered desirable to strive for the technological neutrality of hydrogen production technologies, at least in the first stage of the development of this market, and adopt a definition and classification criteria for obtaining financial aid taking into account the emission criterion and not only the production technology. Development based solely on hydrogen from renewable energy sources will significantly slow down this market's development and exclude countries such as Poland, which 
currently have a relatively low share of renewable energy production. One should also agree with the Polish government's approach regarding the method of regulating the hydrogen infrastructure - freedom of activity should be preferred in the initial stage of development. Covering this market with regulations such as those relating to the natural gas market will make it impossible for many entities that currently have the greatest competence to enter this market, particularly transmission and distribution system operators.

A flexible regulatory approach at the initial stage of the hydrogen market development, including the adoption of a definition of hydrogen based on technological neutrality and ensuring the greatest possible freedom of activity while avoiding over-regulation, is definitely preferred by the Polish government. However, as demonstrated in this article, it seems not entirely in line with the European Commission's approach, which can definitely hinder the implementation of the legislative plans included in the Polish Hydrogen Strategy. Polish regulations should not be adopted until the gas package changes planned by the commission for 2021 are introduced. This means that, at least in this respect, the Polish government should revise its plans to adopt the "Hydrogen Law" in the same year and then adjust the planned regulations so that they are in line with the European ones. Otherwise, it will definitely hinder the development of the hydrogen sector in Poland.

\section{References}

ACER 2020. ACER Report on NRAs Survey - Hydrogen, Biomethane, and Related Network Adaptations. Lublana: Agency for Cooperation of Energy Regulators (ACER).

ACER 2021. When and How to Regulate Hydrogen Networks? "European Green Deal” Regulatory White Paper series (paper \#1) relevant to the European Commission's Hydrogen and Energy System Integration Strategies, Agency for Cooperation of Energy Regulators (ACER), February.

BARNES, A. 2020. Can the current EU regulatory framework deliver decarbonisation of gas? The Oxford Institute for Energy Studies, Energy Insight No. 71. [Online] https://www.oxfordenergy.org/publications/ can-the-current-eu-regulatory-framework-deliver-decarbonisation-of-gas/ [Accessed: 2021-05-17].

Council EU 2020. Council conclusions: Towards a hydrogen market for Europe. Council of the European Union. Brussels, 11 December 2020, No. 13976/20.

CSO 2019a. Energy from renewable sources in 2019 (Energia ze źródeł odnawialnych w 2019). Warszawa: Central Statistical Office (CSO). [Online] https://stat.gov.pl/obszary-tematyczne/srodowisko-energia/energia/energia-ze-zrodel-odnawialnych-w-2019-roku,10,3.html [Accessed: 2021-02-15] (in Polish).

CSO 2019b. Production of industrial products in 2019 (Produkcja wyrobów przemysłowych w 2019). Warszawa: Central Statistical Office. [Online] https://stat.gov.pl/obszary-tematyczne/przemysl-budownictwo-srodki-trwale/przemysl/produkcja-wyrobow-przemyslowych-w-2019-roku,3,17.html [Accessed: 2021-02-15] (in Polish).

Directive EC 2009. Directive 2009/73/EC of the European Parliament and of the Council of 13 July 2009 concerning common rules for the internal market in natural gas and repealing Directive 2003/55/EC (OJ L 211, 14.8.2009, p. 94-136).

EC 2019. Communication from the Commission to the European Parliament, the European Council, the Council, the European Economic and Social Committee and the Committee of the Regions "The European Green Deal”. European Commission. Brussels, 11.12.2019, COM(2019) 640 final. 
EC 2020. Communication from the Commission to the European Parliament, the Council, the European Economic and Social Committee and the Committee of the Regions "A hydrogen strategy for a climateneutral Europe”. European Commission. Brussels, 8.7.2020, COM(2020) 301 final.

EL 1997. The Act of 10 April 1997 on the Energy Law (Ustawa z dnia 10 kwietnia 1997 r. Prawo energetyczne). Journal of Laws from 2020 item 833 consolidated text with amendments. (Dz.U. 2020.833 z późn. zm.) (in Polish).

ENVI 2021. Opinion of the Committee on the Environment, Public Health and Food Safety for the Committee on Industry, Research and Energy on a European strategy for hydrogen (2020/2242(INI)), 2020/2242(INI), 28.1.2021.

FCH 2019. Hydrogen Roadmap Europe, $1^{\text {st }}$ edition, Fuel Cells and Hydrogen 2 Joint Undertaking.

GN 2020. Letter from a coalition led by GasNaturally to executive Vice-President Frans Timmermans calling for inclusion in the strategy all hydrogen pathways, Brussels, 24 June 2020. [Online] https://gasnaturally.eu/wp-content/uploads/2020/06/Wide-industry-coalition-call-for-a-Hydrogen-Strategy-inclusive-of-all-clean-hydrogen-pathways-1.pdf [Accessed: 2021-02-15].

HE 2020. Clean Hydrogen Monitor 2020. Brussels: Hydrogen Europe (HE).

IEA 2019. The Future of Hydrogen, Seizing today's opportunities. International Energy Agency (IEA), June.

IRENA 2019. Hydrogen: A renewable energy perspective. Report prepared for the $2^{\text {nd }}$ Hydrogen Energy Ministerial Meeting in Tokyo, Japan. International Renewable Agency (IRENA).

JАКо́вік, W. 2020. The Commission will allow hydrogen from the refinery thanks to the efforts of Poland, which wants to be a leader (Komisja dopuści wodór z rafinerii dzięki staraniom Polski, która chce być liderem). [Online] https://biznesalert.pl/szary-wodor-rafinerie-polska-startegia-wodorowa-polska-komisja-europejska/ [Accessed: 2021-02-15] (in Polish).

Kanellopoulos, K. and Blanco Reano, H. 2019. The potential role of H2 production in a sustainable future power system - An analysis with METIS of a decarbonised system powered by renewables in 2050. EUR 29695 EN, Publications Office of the European Union, Luxembourg. JRC115958, DOI: $10.2760 / 540707$.

MCE 2021. Polish hydrogen strategy until 2030 with a perspective until 2040 - project (Polska strategia wodorowa do roku 2030 z perspektywa do 2040 r. - projekt). Ministry of Climate and Environment (Ministerstwo Klimatu i Środowiska). [Online] https://www.gov.pl/web/klimat/rozpoczely-sie-konsultacje-publiczne-projektu-polskiej-strategii-wodorowej [Accessed: 2021-02-15] (in Polish).

PEP40 2021. Polish Energy Policy to 2040 (Polityka Energetyczna Polski do 2040 r.). Annex to Resolution No. 22/2021 of the Council of Ministers of Poland of February 2, 2021 (in Polish).

PERZYŃSKI, M. 2021. Eastern Wielkopolska wants to put on green hydrogen (Wielkopolska Wschodnia chce postawić na zielony wodór). [Online] https://biznesalert.pl/energetyka-innowacje-wodor-zielony-oze -wielkopolska/ [Accessed: 2021-02-15] (in Polish).

PIE 2019. Directions of development of the hydrogen economy in Poland (Kierunki rozwoju gospodarki wodorowej $w$ Polsce). Working Paper 7/2019. Polish Economic Institute (Polski Instytut Ekonomiczny (PIE)) (in Polish).

Piebalgs, A. and Jones, Ch. 2021. Hydrogen regulation under time pressure. Florence School of Regulation. [Online]: https://fsr.eui.eu/hydrogen-regulation-under-time-pressure/ [Accessed: 2021-02-15].

Proposal TEN-E 2020. Proposal for a Regulation of the European Parliament and of the Council on guidelines for trans-European energy infrastructure and repealing Regulation (EU) No. 347/2013, $\mathrm{COM} / 2020 / 824$ final.

RED II Directive 2018. Directive 2009/28/EC of the European Parliament and of the Council of 23 April 2009 on the promotion of the use of energy from renewable sources and amending and subsequently repealing Directives 2001/77/EC and 2003/30/EC. (OJ L 140, 5.6.2009, p. 16-62). 
Regulation ME 2010. Regulation of the Minister of Economy of 2 July 2010 on the detailed conditions for the operation of the gas system (Rozporzadzenie Ministra Gospodarki z dnia 2 lipca $2010 \mathrm{r}$. w sprawie szczegółowych warunków funkcjonowania system gazowego). Journal of Laws from 2018 item 1158 consolidated text with amendments (Dz.U. 2018.1158 z późn. zm.) (in Polish).

RES Act 2015. Act of February 20, 2015 on renewable energy sources (Ustawa o odnawialnych źródłach energii). (Dz.U.2021.610 t.j. z późn. zm.) (in Polish).

ZEPAK 2020. Hydrogen production at ZE PAK SA is a new source of fuel for passenger vehicles and buses (Produkcja wodoru w ZE PAK SA to nowe źródło paliwa dla pojazdów osobowych $i$ autobusów). ZE PAK 2020. [Online] https://www.zepak.com.pl/pl/elektrownie/elektrownia-patnow-konin/elektrownia -konin/produkcja-wodoru-w-ze-pak-sa.html [Accessed: 2021-05-18] (in Polish).

Dagmara DRAGAN

\section{Polska Strategia Wodorowa - wyzwania regulacyjne w perspektywie europejskiej}

\section{Streszczenie}

14 stycznia 2021 r. Ministerstwo Klimatu i Środowiska opublikowało i przekazało do konsultacji publicznych projekt Polskiej Strategii Wodorowej do 2030 r. z perspektywą do 2040 r. W projekcie przedstawiono cele i działania, które zmierzać mają do rozwinięcia krajowych kompetencji w zakresie rozwoju technologii wodorowych. Jednym z założeń projektu jest opracowanie „Polskiego prawa wodorowego”ustawy mającej na celu nowelizację innych ustaw istniejących już w polskim porządku prawnym, takich jak Prawo energetyczne. W niniejszym artykule poddano analizie najważniejsze założenia „Polskiego prawa wodorowego", w szczególności w odniesieniu do definicji wodoru oraz przyjęcia kryteriów kwalifikacji technologii jego produkcji do uzyskania wsparcia w ramach Strategii. Podjęto również bardzo istotną kwestię związaną z planowanymi regulacjami dotyczącymi objęcia sektora gospodarki wodorowej tożsamymi regulacjami, jak w przypadku sektora gazu ziemnego, w tym regulacjami dotyczącymi przyszłej infrastruktury wodorowej oraz ich wpływu na dotychczas istniejącą infrastrukturę gazową. Jednym z głównych wniosków tej analizy jest wykazanie, że Polska Strategia Wodorowa nie jest w pełni zgodna z opublikowaną w lipcu 2020 r. przez Komisję Europejską „Strategią w zakresie wodoru na rzecz Europy neutralnej dla klimatu".

SŁowa KLUCzowe: Polska Strategia Wodorowa, wodór, gazy zdekarbonizowane, zielony wodór, Polskie prawo wodorowe 